\title{
Preoperative serum HER2 extracellular domain levels in primary invasive breast cancer
}

Sae Byul Lee ${ }^{1}$, Jong Won Lee ${ }^{1,5^{*}}$, Jong Han Yu' ${ }^{1}$, Beom Seok Ko ${ }^{1}$, Hee Jeong Kim¹, Byung Ho Son ${ }^{1}$, Gyungyub Gong ${ }^{2}$, Hee Jin Lee², Sung-Bae Kim³ ${ }^{3}$ Kyung Hae Jung ${ }^{3}$, Jin-Hee Ahn ${ }^{3}$, Woochang Lee ${ }^{4}$, Joohon Sung ${ }^{5}$ and Sei-Hyun Ahn ${ }^{1}$

\begin{abstract}
Background: Despite the preclinical outcomes and biologic significance of the presence of the human epidermal growth factor receptor-2 (HER2) extracellular domain (ECD), there is little evidence supporting the measurement of ECD levels in any clinical setting. The aim of this study was to determine the prevalence of elevated serum HER2 ECD levels, the association between these levels and tissue HER2 overexpression, and the potential clinical prognostic value of HER2 ECD in primary invasive breast cancer.
\end{abstract}

Methods: Serum HER2 ECD levels were examined preoperatively in 2,862 consecutive stage I-III primary breast cancer patients between 2007 and 2009. Serum HER2 ECD levels were measured by chemiluminescence immunoassay (ADVIA Centaur), and the tissue HER2 status was assessed by immunohistochemistry and fluorescence in situ hybridization. The cutoff value for the serum level of HER2 ECD was set at $15.2 \mathrm{ng} / \mathrm{ml}$.

Results: Among the 2,862 patients, 126 (4.4\%) had elevated serum HER2 ECD levels, and HER2 was overexpressed in the tumor tissue of 692 patients (24.2\%), with a concordance of $78.7 \%$. Multivariate analysis revealed that elevated serum HER2 ECD was a significant independent prognostic factor for worse distant-metastasis-free survival [DMFS; hazard ratio $(\mathrm{HR})=2.50,95 \%$ confidence interval $(\mathrm{Cl})=1.5-4.3, P=0.001$ ] and breast-cancer-specific survival (BCSS; $H R=2.0,95 \% \mathrm{Cl}=1.1-3.8, P=0.036$ ), which were much stronger in patients with tissue HER2-positive tumors (DMFS: $\mathrm{HR}=3.8,95 \% \mathrm{Cl}=2.0-7.0, P<0.001 ; \mathrm{BCSS}: \mathrm{HR}=2.6,95 \% \mathrm{Cl}=1.2-5.3, P=0.012$ ).

Conclusions: Given the prevalence of HER2 expression, its measurement as an independent prognostic factor can be clinically useful, particularly in patients with tissue HER2-positive tumors.

Keywords: HER2 extracellular domain, HER2 breast cancer, Prognostic factor

\section{Background}

Human epidermal growth factor receptor-2 (HER2) overexpression or amplification in tumor tissue is reportedly observed in $20-30 \%$ of primary breast cancers. Tissue HER2 status is now routinely used as an important parameter for decision making regarding anti-HER2 therapy in the neoadjuvant [1], adjuvant [2], and metastatic [3] settings. The presence of HER2 in tumor tissues also adds predictive and prognostic information regarding shorter overall and disease-free survivals [4], preferential benefit

\footnotetext{
* Correspondence: jongwonlee116@gmail.com

'Department of Surgery, University of Ulsan College of Medicine, Asan Medical Center, 388-1 Pungnap 2 dong, Songpa-Gu, Seoul 138-736, Korea ${ }^{5}$ Department of Epidemiology, School of Public Health and Institute of Health and Environment, Seoul National University, Seoul, Korea Full list of author information is available at the end of the article
}

from doxorubicin [5-7], and possible resistance to tamoxifen [8-10]. However, despite the continuous and varying degrees of tissue HER2 expression, tumors are arbitrarily dichotomized into HER2-positive and HER2-negative groups based on immunohistochemistry (IHC) and fluorescence in situ hybridization (FISH) [11]. As a result, the definition of tissue HER2 positivity remains a matter of controversy [12-14]. In addition, there is recent evidence that some tissue HER2-negative patients appear to benefit from trastuzumab $[12,15]$.

Serum HER2 extracellular domain (ECD) can be detectable by the cleavage of transmembrane tissue HER2 protein which is probably mediated by a matrix metalloproteinase [16-18]. Given the same origin of each HER2 subcomponent in tissue and blood, the technical problems 
inherent in current tissue HER2 testing methods have urged the exploration of clinical utilities of serum HER2 ECD [19]. The quantification of serum HER2 ECD in primary breast cancer could theoretically enhance the sensitivity of tissue HER2 testing in the minority population in which HER2 expression is significant, but is not sufficiently high to be considered as HER2-positive by the American Society of Clinical Oncology (ASCO) and College of American Pathologists (CAP) guidelines, possibly due to tumor heterogeneity [11,20-22]. In the metastatic setting, the findings of some studies further suggest that HER2 ECD levels and changes therein reflect the patients' responses to antiestrogen therapy [23,24], chemotherapy $[25,26]$, and trastuzumab $[27,28]$. There have been a few positive results in the adjuvant setting, similar to the metastatic setting [29-33], but most studies have addressed the relationship between abnormal HER2 ECD levels and tissue expression positivity with contradictory results. The current consensus is that although preoperative HER2 ECD appears to be correlated with tumor size and nodal involvement, it may not be related to tissue HER2 status, especially in primary breast cancer, and there is insufficient evidence to support incorporating measurement of this parameter into the routine clinical management of women with breast cancer as an independent prognostic factor $[14,34]$.

The aims of the present study were to establish the prevalence of elevated HER2 ECD levels, and determine whether there is an association between serum HER2 ECD levels and tissue HER2 overexpression in a large number of patients with primary breast cancer, using a single assay approved by the US Food and Drug Administration (FDA). Furthermore, we sought to elucidate differences in any such association between various subgroups of patients, as reported previously [35,36], and to determine the prognostic usefulness of HER2 ECD and derive evidence for verifying previous equivocal reports [14,34].

\section{Methods}

Patients who were diagnosed with and had surgery for stage I-III primary breast cancer at Asan Medical Center between January 2007 and December 2009 were enrolled for this study $(n=2,862)$. Patients with distant metastasis at the time of diagnosis, bilateral cancer, and the initial plan of neoadjuvant systemic therapy were excluded. All of the patients' information and tumor characteristics were retrieved from our prospectively collected database. The size of the tumor, regional lymph node (LN) status, histologic grade, nuclear grade, presence of lymphovascular invasion (LVI), histological subtype, and immunohistochemical status of estrogen receptors, progesterone receptors, and HER2 were determined at our institute by pathological analysis on formalin-fixed paraffin-embedded tissue sections of the primary tumor excised at the time of definitive surgery. Tumor staging followed the tumornode-metastasis classification of the 7th American Joint Committee on Cancer [37]. This study was reviewed and approved by the Institutional Review Board of Asan Medical Center (20141162).

\section{Tissue HER2 immunohistochemistry}

Formalin-fixed, paraffin-embedded sections $(4 \mu \mathrm{m}$ in thickness) were deparaffinized, dehydrated through a graded alcohol series, and subjected to blocking with hydrogen peroxide and allowed to dry for $10 \mathrm{~min}$ at RT, followed by $20 \mathrm{~min}$ in an incubator at $65 \mathrm{C}$. IHC was performed in a BenchMark XT autostainer (Ventana Medical Systems, Tucson, AZ) using OptiView DAB Detection Kit (Ventana Medical Systems) for HER2 (cat. 800-4422, clone 4B5, dilution 1:8, Ventana Medical Systems, Tucson, AZ, USA).

The results were graded according to the level of coloring of cell membrane of cancer cells. The cases where less than $10 \%$ of the tumors cells stained positively were graded as 0 , cases where membrane staining was partial but occurred in greater than $10 \%$ of the tumor cells were scored as $1+$, cases where entire cell membranes stained modestly were graded as $2+$, and cases where entire cell membranes stained strongly but occurred in greater than $30 \%$ of the tumor cells were graded 3+. Cases graded 3+ were automatically considered positive, while tumors graded 2+ were further evaluated by fluorescence in situ hybridization (FISH) using the Abbott PathVysion HER2 DNA Probe Kit protocol (Abbott Laboratories, Abbott Park, Des Plaines, USA), with additional monitoring for the progress of proteolytic digestion by propidium iodide staining. Probe mixes were hybridized at $37^{\circ} \mathrm{C}$ between 14 and18h. After hybridizations, slides were washed in $2 \times$ SSC $/ 0.3 \% \mathrm{NP}-40$ at $72^{\circ} \mathrm{C}$ for $30 \mathrm{~min}$, air dried, and counterstained with DAPI. The results were reported as the ratio between the average copy number of the HER2 gene and that of the chromosome 17 centromere, analyzing 20 neoplastic nuclei. Specimens with a signal ratio of $<1.8$ were considered negative for HER2 gene amplification, whereas those with a signal ratio $>2.2$ were considered positive for $H E R 2$ gene amplification. If a signal ratio fell on or between the values of 1.8 and 2.2, we counted the number of signals in an additional 20 nuclei in a second target area. The signal ratio was then calculated from both target areas (40 cells).

\section{Serum HER2 ECD assay}

Serum samples were obtained from breast cancer patients at our cancer center at the time of cancer diagnosis; $5 \mathrm{ml}$ of blood was drawn into serum-separation tubes before surgery and then subjected to chemiluminescence immunoassay. The serum HER2 ECD test is a two-site sandwich immunoassay using two monoclonal antibodies that 
Table 1 Distributions of serum human epidermal growth factor receptor-2 (HER2) extracellular domain (ECD) levels and proportions of patients with elevated serum HER2 ECD levels (i.e., $>15.2 \mathrm{ng} / \mathrm{ml}$ ) according to subgroups stratified according to various clinicopathologic variables $(n=2,862)$

\begin{tabular}{|c|c|c|c|c|c|c|}
\hline \multirow{2}{*}{$\begin{array}{l}\text { Subgroup classified by } \\
\text { variables }\end{array}$} & \multirow[t]{2}{*}{$n(\%)$} & \multicolumn{2}{|c|}{ Serum HER2 ECD level (ng/ml) } & \multirow[t]{2}{*}{$P^{a}$} & \multicolumn{2}{|c|}{ Patients with HER2 ECD $>15.2 \mathrm{ng} / \mathrm{m}$} \\
\hline & & Mean \pm SD & Median (range) & & $n$ & $\%^{\mathbf{b}}$ \\
\hline Total patients & $2,862(100 \%)$ & $10.1 \pm 9.4$ & $9.2(3.3-427.8)$ & & 126 & $4.4 \%$ \\
\hline Age, years & & & & 0.149 & & \\
\hline$\leq 34$ & $172(6 \%)$ & $10.1 \pm 5.6$ & $8.8(4.8-56.0)$ & & 10 & $5.8 \%$ \\
\hline $35-49$ & $1,510(53 \%)$ & $9.8 \pm 12.1$ & $8.8(3.3-427.8)$ & & 55 & $3.6 \%$ \\
\hline$\geq 50$ & $1,180(41 \%)$ & $10.5 \pm 9.4$ & $9.8(4.4-90.1)$ & & 61 & $5.2 \%$ \\
\hline Stage & & & & $<0.001$ & & \\
\hline$|/| \mid$ & $2,457(86 \%)$ & $9.6 \pm 4.6$ & $9.1(3.3-184.3)$ & & 81 & $3.3 \%$ \\
\hline III & $405(14 \%)$ & $12.8 \pm 22.1$ & $10.1(5.5-427.8)$ & & 45 & $11.1 \%$ \\
\hline Tumor size, cm & & & & 0.001 & & \\
\hline$\leq 2$ & $1,676(59 \%)$ & $9.6 \pm 5.1$ & $9.0(3.3-184.3)$ & & 51 & $3.0 \%$ \\
\hline$>2$ & $1,186(41 \%)$ & $10.8 \pm 13.2$ & $9.5(3.8-427.8)$ & & 75 & $6.3 \%$ \\
\hline Lymph node & & & & $<0.001$ & & \\
\hline Negative & $1,749(61 \%)$ & $9.6 \pm 3.0$ & $9.0(3.3-48.2)$ & & 55 & $3.1 \%$ \\
\hline Positive & $1,113(39 \%)$ & $11.0 \pm 14.6$ & $9.4(4.3-427.8)$ & & 71 & $6.4 \%$ \\
\hline \multicolumn{7}{|l|}{ Histologic grade } \\
\hline $1 / 2$ & $1,787(64 \%)$ & $9.7 \pm 5.5$ & $9.0(3.8-184.3)$ & 0.002 & 53 & $3.0 \%$ \\
\hline 3 & $1,025(36 \%)$ & $10.8 \pm 13.8$ & $9.5(4.6-427.8)$ & & 71 & $6.9 \%$ \\
\hline Unknown & 50 & & & & 2 & \\
\hline Nuclear grade & & & & 0.006 & & \\
\hline $1 / 2$ & $1,775(63 \%)$ & $9.6 \pm 5.4$ & $9.0(3.3-184.3)$ & & 45 & $2.5 \%$ \\
\hline 3 & $1,049(37 \%)$ & $10.6 \pm 13.6$ & $9.4(4.6-427.8)$ & & 65 & $6.2 \%$ \\
\hline Unknown & 38 & & & & 16 & \\
\hline LVI & & & & 0.018 & & \\
\hline Negative & $2,095(76 \%)$ & $9.8 \pm 3.7$ & $9.1(3.3-67.5)$ & & 88 & $4.2 \%$ \\
\hline Positive & $660(24 \%)$ & $10.3 \pm 8.5$ & $9.3(3.8-184.3)$ & & 29 & $4.4 \%$ \\
\hline Unknown & 107 & & & & 9 & \\
\hline Hormone-receptor status & & & & $<0.001$ & & \\
\hline Negative & $916(32 \%)$ & $11.5 \pm 15.0$ & $9.8(4.6-427.8)$ & & 85 & $9.3 \%$ \\
\hline Positive $^{c}$ & $1,940(68 \%)$ & $9.5 \pm 4.7$ & $9.0(3.3-184.3)$ & & 41 & $2.1 \%$ \\
\hline Unknown & 6 & & & & 0 & \\
\hline Tissue HER2 status & & & & $<0.001$ & & \\
\hline Negative & $2,168(76 \%)$ & $9.3 \pm 4.3$ & $8.9(3.8-184.3)$ & & 22 & $1.0 \%$ \\
\hline Positive $^{d}$ & $692(24 \%)$ & $12.8 \pm 17.3$ & $10.6(3.3-427.8)$ & & 104 & $15.0 \%$ \\
\hline Unknown & 2 & & & & 0 & \\
\hline Definitive surgery & & & & $<0.001$ & & \\
\hline Conservation & $1,781(62 \%)$ & $9.3 \pm 2.5$ & $8.9(3.3-44.8)$ & & 38 & $2.1 \%$ \\
\hline Mastectomy & $1,081(38 \%)$ & $11.4 \pm 14.9$ & $9.7(4.3-427.8)$ & & 88 & $8.1 \%$ \\
\hline Radiotherapy & & & & 0.135 & & \\
\hline Yes & $2,047(72 \%)$ & $9.9 \pm 10.2$ & $9.1(3.3-427.8)$ & & 74 & $3.6 \%$ \\
\hline No & $813(28 \%)$ & $10.5 \pm 7.1$ & $9.6(4.3-184.3)$ & & 52 & $6.4 \%$ \\
\hline Unknown & 2 & & & & 0 & \\
\hline
\end{tabular}


Table 1 Distributions of serum human epidermal growth factor receptor-2 (HER2) extracellular domain (ECD) levels and proportions of patients with elevated serum HER2 ECD levels (i.e., $>15.2 \mathrm{ng} / \mathrm{ml}$ ) according to subgroups stratified according to various clinicopathologic variables $(n=2,862)$ (Continued)

\begin{tabular}{|c|c|c|c|c|c|c|}
\hline Chemotherapy & & & & $<0.001$ & & \\
\hline Yes & $1,852(65 \%)$ & $10.6 \pm 11.5$ & $9.4(4.3-427.8)$ & & 106 & $5.7 \%$ \\
\hline No & 1,007 (35\%) & $9.2 \pm 2.6$ & $8.9(3.3-35.6)$ & & 20 & $2.0 \%$ \\
\hline Unknown & 3 & & & & 0 & \\
\hline Anti-HER2 therapy & & & & $<0.001$ & & \\
\hline Yes & $264(9 \%)$ & $15.0 \pm 27.2$ & $11.0(4.3-427.8)$ & & 53 & $20.1 \%$ \\
\hline No & 2,598 (91\%) & $9.6 \pm 4.4$ & $9.1(3.3-184.3)$ & & 73 & $2.8 \%$ \\
\hline
\end{tabular}

${ }^{\mathrm{a}}$ Calculated by ANOVA.

bPercentage calculated by dividing the number of patients with elevated serum HER2 ECD level ( $>15.2 \mathrm{ng} / \mathrm{ml}$ ) by the total number of patients in each subgroup. ${ }^{\mathrm{c}}$ Estrogen- and/or progesterone-receptor positive.

${ }^{\mathrm{d}}$ Graded as $3+$ on immunohistochemistry $(\mathrm{IHC})$ or $2+$ on fluorescence in situ hybridization in cases of IHC $2+$.

LVI lymphovascular invasion.

combine specifically with the HER2 ECD through direct chemiluminescence (ADVIA Centaur System, Siemens Healthcare, Tarrytown, NY, USA). Measurements were performed strictly according to the manufacturer's instructions and quality control was ensured. The serum HER2 ECD assay for each patient was performed as part of the routine preoperative work-up procedures at the Department of Laboratory Medicine, and the results were stored in our database. We used the manufacturer's recommended cutoff value of $15.2 \mathrm{ng} / \mathrm{ml}$.

\section{Statistical analysis}

Distant-metastasis-free survival (DMFS) was defined as the time from surgery to the first appearance of distant metastasis. Breast-cancer-specific survival (BCSS) was defined as the time from surgery to the time of breastcancer-specific death. Correlations between elevated serum HER2 ECD and several variables were evaluated using the chi-square test, and the means of continuous variables such as age and serum HER2 ECD among different groups were compared using ANOVA. Survival curves were generated using the Kaplan-Meier method, and the significance of survival differences among selected variables was verified using the log-rank test. The Cox proportional-hazards model was used to evaluate the independent prognostic effect of serum HER2 ECD on DMFS and BCSS. Unless stated otherwise, the data are presented as mean $\pm \mathrm{SD}$, and the cutoff for statistical significance was set at $P<0.05$. All statistical analyses were performed using SPSS version 12.0 (SPSS, Chicago, IL, USA).

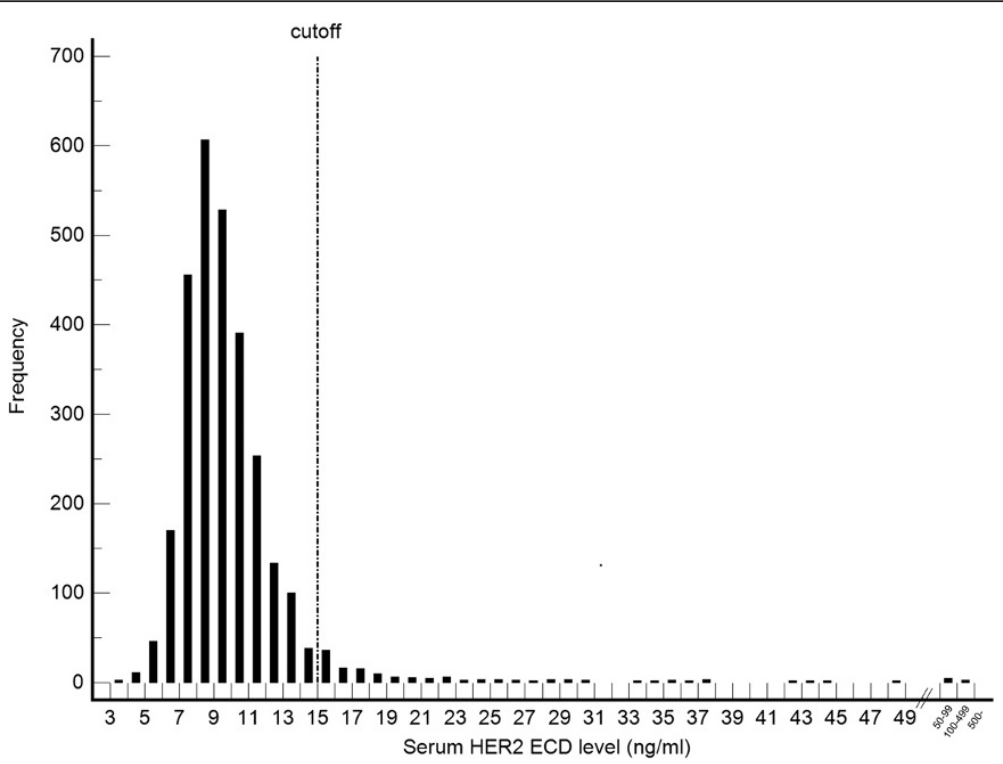

Figure 1 Histogram showing the frequencies of serum human epidermal growth factor receptor-2 (HER2) extracellular domain (ECD) levels $(\mathrm{ng} / \mathrm{ml})$ in 2,862 patients with primary invasive breast cancer. 
Table 2 Baseline characteristics and association between dichotomized serum HER2 ECD level and clinicopathologic variables

\begin{tabular}{|c|c|c|c|c|c|c|c|}
\hline \multirow[t]{2}{*}{ Characteristics } & \multicolumn{2}{|c|}{ Total group } & \multicolumn{2}{|c|}{$\begin{array}{c}\text { Subgroup with normal serum HER2 } \\
\text { ECD level }(\leq 15.2 \mathrm{ng} / \mathrm{ml})\end{array}$} & \multicolumn{2}{|c|}{$\begin{array}{l}\text { Subgroup with elevated serum } \\
\text { HER2 ECD level (>15.2 ng/ml) }\end{array}$} & \multirow[t]{2}{*}{$P^{a}$} \\
\hline & $n$ & $\%$ & $n$ & $\%$ & $n$ & $\%$ & \\
\hline Total patients & 2,862 & $100 \%$ & 2,736 & $100 \%$ & 126 & $100 \%$ & \\
\hline \multicolumn{8}{|l|}{ Serum HER2 ECD, ng/ml } \\
\hline Mean \pm SD & \multicolumn{2}{|c|}{$10.1 \pm 9.4$} & \multicolumn{2}{|c|}{$9.3 \pm 1.9$} & \multicolumn{2}{|c|}{$27.3 \pm 40.4$} & $<0.001^{\mathrm{b}}$ \\
\hline Median (range) & \multicolumn{2}{|c|}{$9.2(3.3-427.8)$} & \multicolumn{2}{|c|}{$9.1(3.3-15.2)$} & \multicolumn{2}{|c|}{$18.5(15.3-427.8)$} & \\
\hline Age at diagnosis, years & & & & & & & $0.860^{\mathrm{b}}$ \\
\hline Mean \pm SD & \multicolumn{2}{|c|}{$48.5 \pm 9.9$} & \multicolumn{2}{|c|}{$48.5 \pm 9.9$} & \multicolumn{2}{|c|}{$48.4 \pm 10.3$} & \\
\hline Median (range) & \multicolumn{2}{|c|}{$48(22-94)$} & \multicolumn{2}{|c|}{$48.0(22-94)$} & \multicolumn{2}{|c|}{$49.0(26-88)$} & \\
\hline
\end{tabular}

Age subgroup, years

$\begin{array}{lccc}\leq 34 & 172 & 6 \% & 162 \\ 35-49 & 1,510 & 53 \% & 1,455 \\ \geq 50 & 1,180 & 41 \% & 1,119\end{array}$

$\begin{array}{ll}6 \% & 10 \\ 53 \% & 55 \\ 41 \% & 61\end{array}$

Stage

|/II

III

$2,457 \quad 86 \%$

2,376

405

$14 \%$

360

$87 \%$

$13 \%$

Tumor size, $\mathrm{cm}$

$$
\leq 2
$$

1,676

$59 \%$

1,625

1,111

Lymph node

Negative

1,186

$41 \%$

$59 \%$

$41 \%$

1,694

1,042

Histologic grade

$1 / 2$
3
Unknown

Nuclear grade

$$
\begin{aligned}
& 1 / 2 \\
& 3 \\
& \text { Unknown }
\end{aligned}
$$

$\begin{array}{ll}1,749 & 61 \% \\ 1,113 & 39 \%\end{array}$

$62 \%$

$38 \%$

$65 \%$

$35 \%$

1,025

1,734

954

48

LVI

Negative
Positive

Unknown

$\begin{array}{ll}1,775 & 63 \% \\ 1,049 & 37 \% \\ 38 & \end{array}$

1,730

984

22

$64 \%$

$36 \%$

2,007

631

98

Hormone-receptor status

Negative
Positive $^{c}$

$\begin{array}{cc}916 & 32 \% \\ 1,940 & 68 \% \\ 6 & \end{array}$

831

1,899

Unknown

$\begin{array}{lccc}\text { Negative } & 2,168 & 76 \% & 2,146 \\ \text { Positive }^{d} & 692 & 24 \% & 588 \\ \text { Unknown } & 2 & & 2\end{array}$

2,146

588

2

Definitive surgery 
Table 2 Baseline characteristics and association between dichotomized serum HER2 ECD level and clinicopathologic variables (Continued)

\begin{tabular}{|c|c|c|c|c|c|c|c|}
\hline Conservation & 1,781 & $62 \%$ & 1,743 & $64 \%$ & 38 & $30 \%$ & \\
\hline Mastectomy & 1,081 & $38 \%$ & 993 & $36 \%$ & 88 & $70 \%$ & \\
\hline \multicolumn{8}{|l|}{ Radiotherapy } \\
\hline Yes & 2,047 & $72 \%$ & 1,973 & $72 \%$ & 74 & $59 \%$ & \multirow[t]{3}{*}{0.001} \\
\hline No & 813 & $28 \%$ & 761 & $28 \%$ & 52 & $41 \%$ & \\
\hline Unknown & 2 & & 2 & & 0 & & \\
\hline \multicolumn{8}{|l|}{ Chemotherapy } \\
\hline Yes & 1,852 & $65 \%$ & 1,746 & $64 \%$ & 106 & $84 \%$ & \multirow[t]{3}{*}{$<0.00$} \\
\hline No & 1,007 & $35 \%$ & 987 & $36 \%$ & 20 & $16 \%$ & \\
\hline Unknown & 3 & & 3 & & 0 & & \\
\hline \multicolumn{8}{|c|}{ Anti-HER2 therapy } \\
\hline Yes & 264 & $9 \%$ & 211 & $8 \%$ & 53 & $42 \%$ & \multirow[t]{2}{*}{$<0.00$} \\
\hline No & 2,598 & $91 \%$ & 2,525 & $92 \%$ & 73 & $58 \%$ & \\
\hline
\end{tabular}

${ }^{a}$ Calculated by chi-square test except where stated otherwise.

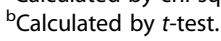

${ }^{\mathrm{C}}$ Estrogen- and/or progesterone-receptor positive.

${ }^{\mathrm{d}}$ Graded as $3+$ on $\mathrm{IHC}$ or $2+$ on fluorescence in situ hybridization in cases of $\mathrm{IHC} 2+$

\section{Results}

\section{Patient characteristics}

The age of the entire cohort ( $n=2,862$ patients) was $48.5 \pm 9.9$ years (range, $22-94$ years), and the numbers of patients at stages I, II, and III were 1,245 (43.5\%), $1,212(42.3 \%)$, and $405(14.2 \%)$, respectively. LN metastasis was detected in 1,113 patients (38.9\%), and positive hormone-receptor status was found in 1,940 patients (67.8\%). Tissue HER2 positivity was detected by IHC and FISH in 692 patients (24.2\%), among which 264 patients
(38.2\%) received adjuvant anti-HER2 therapy with trastuzumab. The details of the patient characteristics are summarized in Table 1.

\section{Distribution and prevalence of preoperative serum HER2} ECD levels in primary breast cancer

The HER2 ECD level before surgery was $10.1 \pm 9.4 \mathrm{ng} / \mathrm{ml}$ (Table 1); 2,736 patients (95.6\%) had an HER2 ECD level of $\leq 15.2 \mathrm{ng} / \mathrm{ml}$, while in $126(4.4 \%)$ the HER2 ECD level exceeded that cutoff value (Table 1 and Figure 1). The

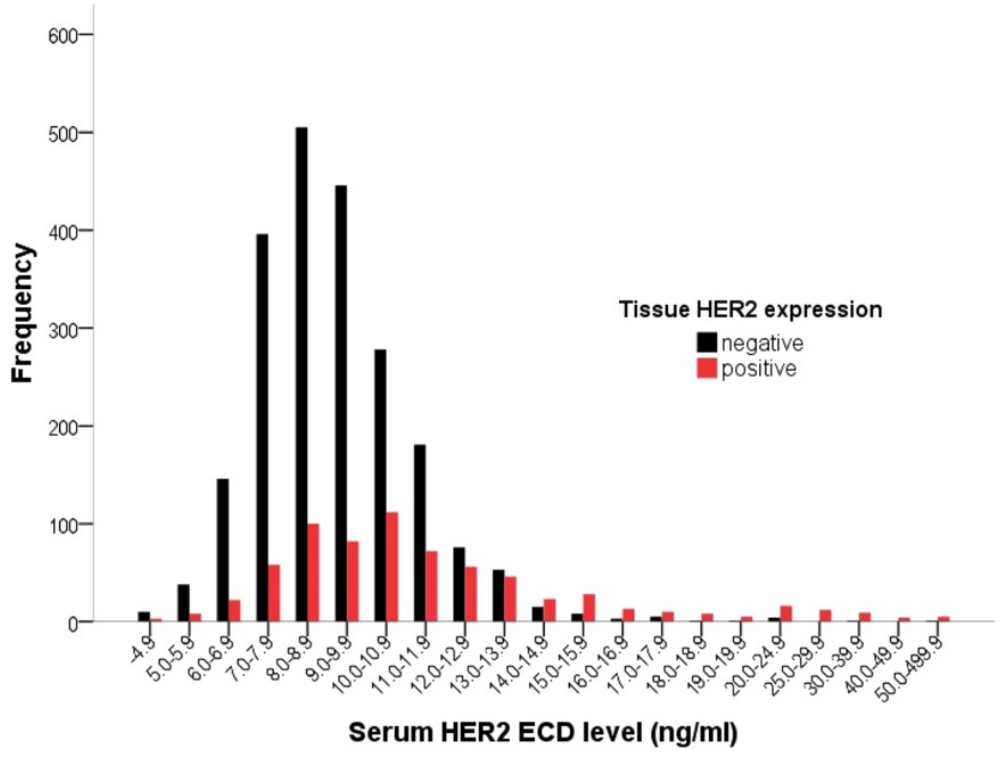

Figure 2 Distribution of serum HER2 ECD levels according to tissue HER2 status: tissue HER2 positive and negative cases are depicted in red and black, respectively. 
HER2 ECD levels in the normal and elevated HER2 ECD groups were $9.3 \pm 1.9$ and $27.3 \pm 40.4 \mathrm{ng} / \mathrm{ml}$, respectively (Table 2).

The distribution of preoperative HER2 ECD levels, which ranged from 3.3 to $427.8 \mathrm{ng} / \mathrm{ml}$, shows a positive skew (i.e., the mass of the distribution was concentrated to the left of the histogram), and the presence of outliers at extremely high values (Figure 1). The majority of the extremely high values belonged to the tissue HER2positive group. When depicted again according to the tissue HER2-expression, it was found that the tissue HER2-positive group had more variable distribution pattern than their tissue HER2-negative counterparts (Table 1 and Figure 2).

Patients with elevated HER2 ECD levels were more likely to have aggressive clinicopathologic variables (Table 2). Age at diagnosis was not related to HER2 ECD levels (Tables 1 and 2). The proportions of patients with elevated ECD level according to various subgroups are summarized in Table 1 . In the tissue HER2-positive subgroup, $15.0 \%$ of the patients had elevated HER2 ECD, which is more than three times the average (4.4\%). Furthermore, the proportion of patients with elevated HER2 ECD levels increased with more advanced

Table 3 Prediction performance of tissue HER2 status and concordance with serum HER2 ECD level

\begin{tabular}{|c|c|c|c|c|c|c|c|c|}
\hline \multirow[t]{2}{*}{ Group analyzed $^{a}$} & \multicolumn{2}{|c|}{ Cross-table } & \multirow[t]{2}{*}{$P^{\mathrm{b}}$} & \multirow{2}{*}{$\begin{array}{c}\text { Concordance } \\
\text { rate }\end{array}$} & \multicolumn{4}{|c|}{ Prediction performance } \\
\hline & & & & & Sensitivity & Specificity & PPV & NPP \\
\hline \multicolumn{3}{|l|}{ (1) Total patients $(n=2,860)$} & $<0.001$ & 78.7 & 15.0 & 99.0 & 82.5 & 78.5 \\
\hline & Tissue $(+)^{\mathrm{e}}$ & Tissue $(-)^{f}$ & & & & & & \\
\hline Elevated $^{c}$ & 104 & 22 & & & & & & \\
\hline Normal ${ }^{d}$ & 588 & 2,146 & & & & & & \\
\hline \multicolumn{3}{|c|}{ (2) Total patients $(n=2,860)$ HER2 ECD cutoff $=10.2 \mathrm{ng} / \mathrm{ml}$} & $<0.001$ & 70.4 & 54.9 & 75.3 & 41.5 & 84.0 \\
\hline & Tissue(+) & Tissue (-) & & & & & & \\
\hline Elevated & 380 & 535 & & & & & & \\
\hline Normal & 312 & 1,633 & & & & & & \\
\hline \multicolumn{3}{|c|}{ (3) Negative lymph node status $(n=1,747)$} & $<0.001$ & 80.3 & 11.2 & 99.1 & 76.4 & 80.4 \\
\hline & Tissue(+) & Tissue(-) & & & & & & \\
\hline Elevated & 42 & 13 & & & & & & \\
\hline Normal & 332 & 1,360 & & & & & & \\
\hline \multicolumn{3}{|c|}{ (4) Positive lymph node status $(n=1,113)$} & $<0.001$ & 76.2 & 19.5 & 98.9 & 87.3 & 75.4 \\
\hline & Tissue(+) & Tissue(-) & & & & & & \\
\hline Elevated & 62 & 9 & & & & & & \\
\hline Normal & 256 & 786 & & & & & & \\
\hline \multicolumn{3}{|l|}{ (5) Stage I $(n=1,243)$} & $<0.001$ & 80.4 & 9.6 & 99.2 & 75.8 & 80.5 \\
\hline & Tissue(+) & Tissue(-) & & & & & & \\
\hline Elevated & 25 & 8 & & & & & & \\
\hline Normal & 236 & 974 & & & & & & \\
\hline \multicolumn{3}{|l|}{ (6) Stage II $(n=1,212)$} & $<0.001$ & 78.7 & 13.3 & 98.9 & 79.2 & 78.7 \\
\hline & Tissue(+) & Tissue(-) & & & & & & \\
\hline Elevated & 38 & 10 & & & & & & \\
\hline Normal & 248 & 916 & & & & & & \\
\hline \multirow[t]{2}{*}{ (7) Stage III $(n=405)$} & & & $<0.001$ & 73.3 & 28.3 & 98.5 & 91.1 & 71.1 \\
\hline & Tissue(+) & Tissue(-) & & & & & & \\
\hline Elevated & 41 & 4 & & & & & & \\
\hline Normal & 104 & 256 & & & & & & \\
\hline
\end{tabular}

${ }^{a}$ A diagnostic cutoff value of $15.2 \mathrm{ng} / \mathrm{ml}$ was used except where stated otherwise.

${ }^{\mathrm{b}}$ Calculated by chi-square test.

'Elevated serum HER2 ECD level.

${ }^{\mathrm{d}}$ Normal serum HER2 ECD level.

e Defined as 3+ on IHC or amplification on fluorescence in situ hybridization in cases of IHC 2+.

fTissue HER2 negative.

PPV positive predictive value, NPV negative predictive value. 
and aggressive tumors: $11.3 \%$ of those at stage III, $9.3 \%$ of those with negative hormone-receptor status, $6.9 \%$ of those with high-grade disease, $6.4 \%$ of those with positive LN metastasis, and $6.3 \%$ of those with a tumor size of $>2 \mathrm{~cm}$. Among the 2,168 patients with negative tissue HER2 status, only 22 (1.0\%) had a level of HER2 ECD greater than the cutoff value.

\section{Serum HER2 ECD levels and tissue HER2 status}

Of the patients for whom tissue HER2 status could be determined by IHC and/or FISH $(n=2,860), 692(24.2 \%)$ had a positive tissue HER2 status. There was a strong statistical correlation between serum HER2 ECD levels and tissue HER2 status in terms of the difference in serum HER2 ECD values $(12.8 \pm 17.3$ and $9.3 \pm 4.3 \mathrm{ng} / \mathrm{ml}$, respectively; $P<0.001$; Table 1 ) as well as the proportion of patients with elevated serum HER2 ECD level (15.0\% and $1.0 \%$, respectively; $P<0.001$; Table 1 ) in tissue HER2positive and -negative subgroups. The overall concordance rate was $78.7 \%$, with a sensitivity of $15.0 \%$ and a specificity of $99.0 \%$. In addition, a better sensitivity (54.9\%) was obtained when we applied a different cutoff value of $10.2 \mathrm{ng} / \mathrm{ml}$ (rather than $15.2 \mathrm{ng} / \mathrm{ml}$ ), which has been suggested as an alternative cutoff value for Korean populations [31], but the superior specificity (75.3\%) and overall concordance rate $(70.4 \%)$ were not retained [Table 3-(1), (2)].
As indicated in Figure 3 and Table 3, a series of receiver operating characteristic (ROC) analyses was performed to determine differences in the concordance between the serum and tissue status according to various subgroups, using the cutoff value of $15.2 \mathrm{ng} / \mathrm{ml}$, as used in previous studies $[35,36]$. There was a trend toward an improvement in sensitivities and area under the ROC curve (AUC), while retaining good specificities and concordance rates ( $\geq 98.5 \%$ and $\geq 73.3 \%$ in all subgroups, respectively) with disease status progression (LN negative $v s$ positive: sensitivity $=11.2 \%$ vs $19.5 \%$; stage I vs II $v s$ III: sensitivity $=9.6 \%$ vs $13.3 \%$ vs $28.3 \%$; LN negative vs positive: $\mathrm{AUC}=0.659$ vs 0.738; stage I vs II vs III: $\mathrm{AUC}=0.620$ vs 0.721 vs 0.778).

\section{Prognostic value of serum HER2 ECD level}

The median follow-up period of all the patients was 46 months (range, 0-75 months). The 5-year distantmetastasis-free survival (DMFS) rate was $81.4 \%$ for patients with elevated HER2 ECD and 93.6\% for those with normal HER2 ECD (log-rank $P<0.001$; Figure 4A); and corresponding 5-year breast-cancer-specific survival (BCSS) rates were $85.3 \%$ and $95.1 \%$ (log-rank $\mathrm{P}<0.001$; Figure 5A).

Figures 4 and 5 show the results of subgroup analyses. In the log-rank test, an elevated HER2 ECD level (i.e., $>15.2 \mathrm{ng} / \mathrm{ml}$ ) was of prognostic value in terms of DMFS, irrespective of tumor size, hormone-receptor status, and anti-HER2 therapy (Figure 4B,D,F). Furthermore,
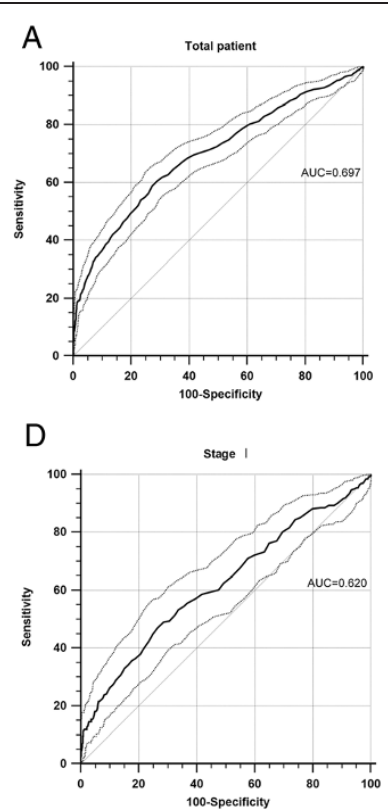

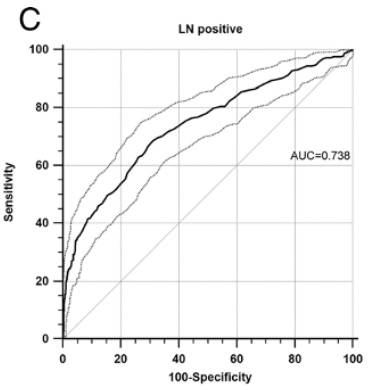

F
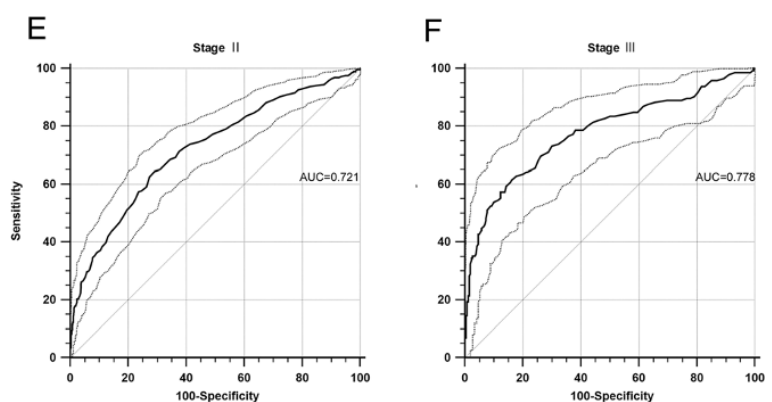

Figure 3 Receiver operating characteristic (ROC) curves of serum HER2 ECD for predicting the status of tissue HER2 positivity with 95\% confidence interval ( $\mathrm{Cl}$; dotted line). (A) The area under the ROC curve (AUC) for the entire cohort of 2,860 patients was 0.697 (95\% $\mathrm{Cl}=0.679-0.714, P<0.001)$. In subgroup analyses, AUCs tended to increase with indexes of the tumor extent: $(\mathbf{B}, \mathbf{C}) \mathrm{AUC}(95 \% \mathrm{Cl})=0.659$ (0.637-0.682)/0.783 (0.711-0.763) in lymph node (LN)-negative/-positive subgroups; and (D-F) AUC (95\% Cl) $=0.620(0.592-0.647) / 0.720$ $(0.695-0.746) / 0.778(0.734-0.818)$ in stage $\mathrm{I} / \mathrm{II} / \mathrm{III}$ subgroups. The $P$ values of all ROC curves were $<0.001$. 

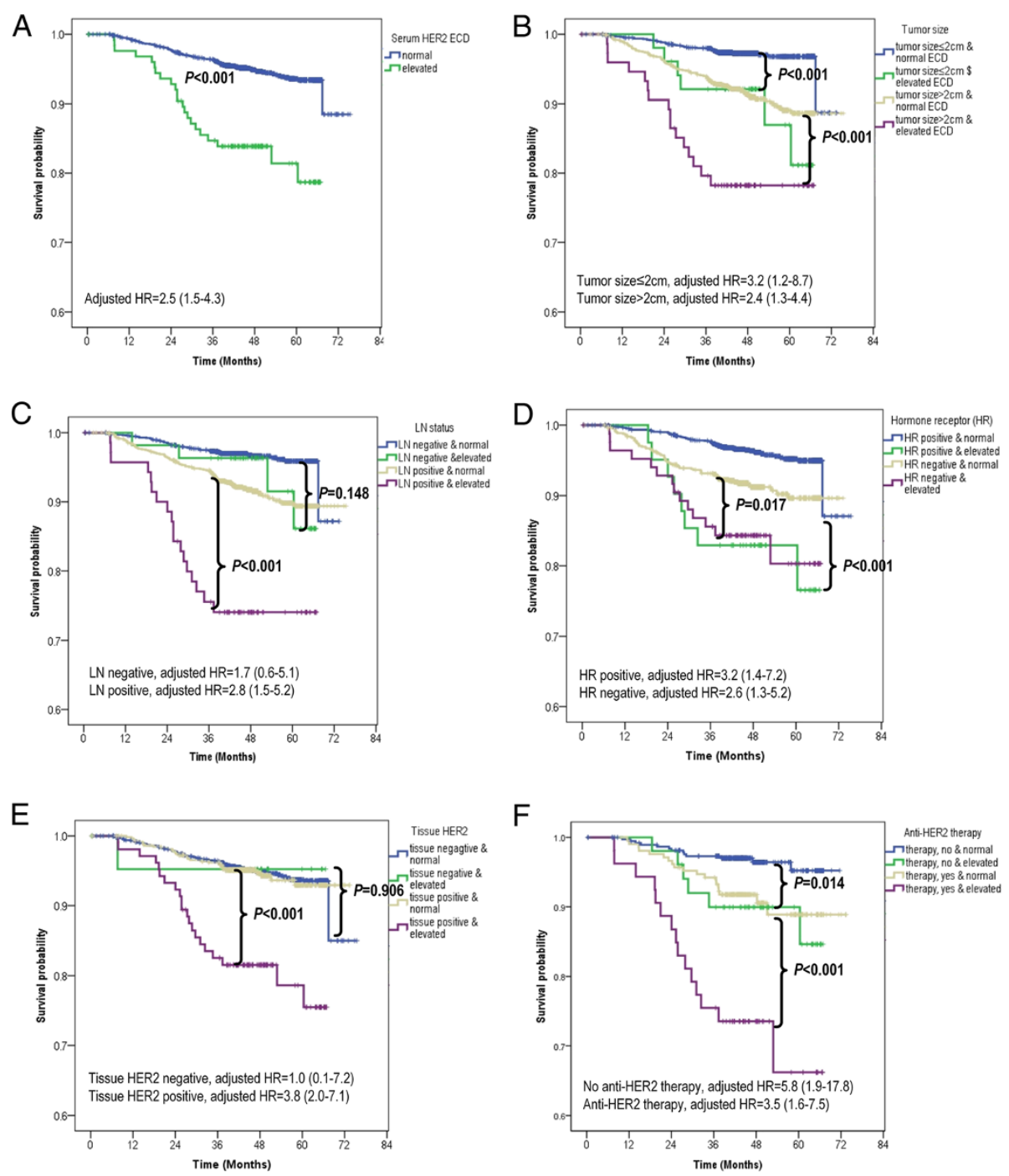

Figure 4 Distant-metastasis-free survival (DMFS) according to serum HER2 ECD level. (A) DMFS according to serum HER2 ECD level [elevated level $(>15.2 \mathrm{ng} / \mathrm{ml})$ vs normal level $(\leq 15.2 \mathrm{ng} / \mathrm{ml})$ ] in the overall series. Elevated serum HER2 ECD level was an independent prognostic factor [log-rank $\mathrm{P}<0.001$, adjusted hazard ratio $(\mathrm{HR})=2.5$, and $95 \% \mathrm{Cl}=1.5-4.3]$. (B-F) Subgroup analyses by tumor size (B), LN status (C), hormone-receptor status (D), tissue HER2 status (E), and anti-HER2 therapy (F). (A-F) Elevated serum HER2 ECD level was significantly prognostic in all subgroups except in those with $L N$ negativity (log-rank $P=0.148$, adjusted $H R=1.7,95 \% \mathrm{Cl}=0.6-5.1$ ) and negative tissue HER2 status (log-rank $P=0.906$, adjusted $\mathrm{HR}=1.0,95 \% \mathrm{Cl}=0.1-7.2$.). All HRs were adjusted according to the following eight variables: tumor size, $\mathrm{LN}$ status, tumor grade, lymphovascular invasion, tissue HER2 status, chemotherapy, antihormone therapy, and trastuzumab therapy.

elevated HER2 ECD level was found to be a significant prognostic factor in subgroups with positive LN status and tissue HER2 overexpression (log-rank $P<0.001$ and $<0.001$, respectively), but not in those with negative LN and negative tissue HER2 status (log-rank $P=0.148$ and 0.906, respectively; Figure 4C,-E). Although in terms of BCSS, elevated HER2 ECD levels were significant in all 2,862 patients (log-rank $P<0.001)$ and in subgroups with any tumor size, with any LN status, with positive hormone-receptor status, and with positive tissue HER2 status, adjusted hazard ratios (HRs) calculated for each subgroup revealed none to be independently significant, except in a subgroup with positive tissue HER2 status [log-rank $P<0.001$, adjusted $\mathrm{HR}=2.6,95 \%$ confidence interval $(\mathrm{CI})=1.2-5.3$; Figure 5E]. Adjusted HRs of an elevated HER2 ECD level (depicted in Figures 4 and 5) showed the same trend of prognostic significance as in the log-rank test. Statistically adjusted prognostic values in subgroups according to anti-HER2 therapy in patients with positive tissue HER2 expression were observed significant in both subgroups in terms of DMFS, but only in the nontrastuzumab subgroup in terms of BCSS (Figures $4 \mathrm{~F}$ and $5 \mathrm{~F}$ ). 


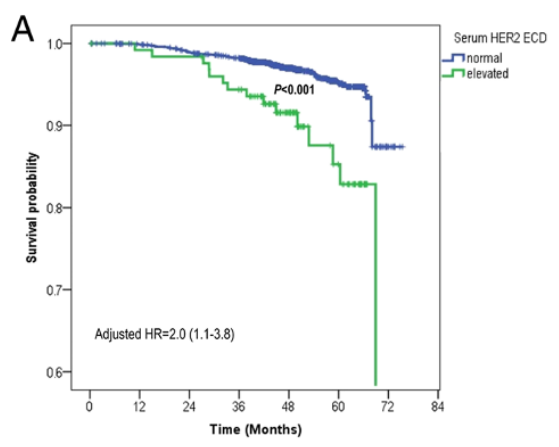

C

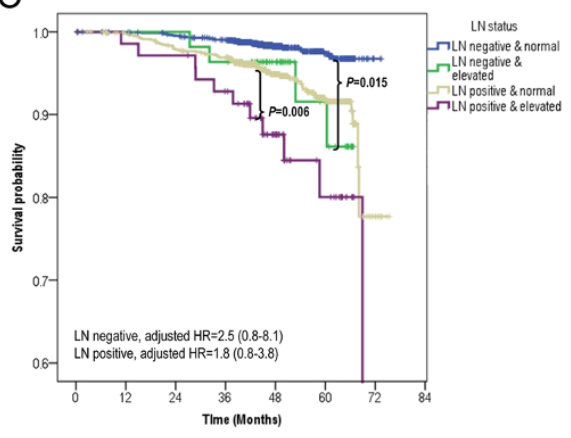

$\mathrm{E}$

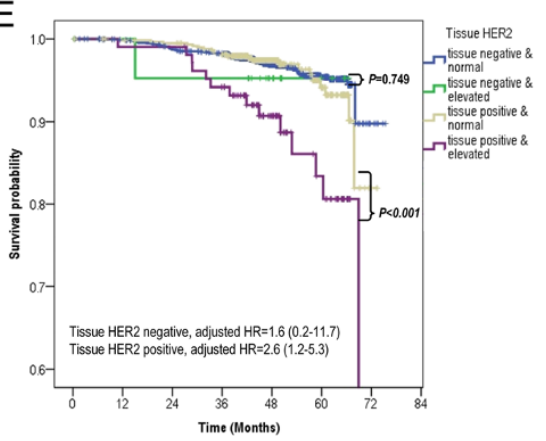

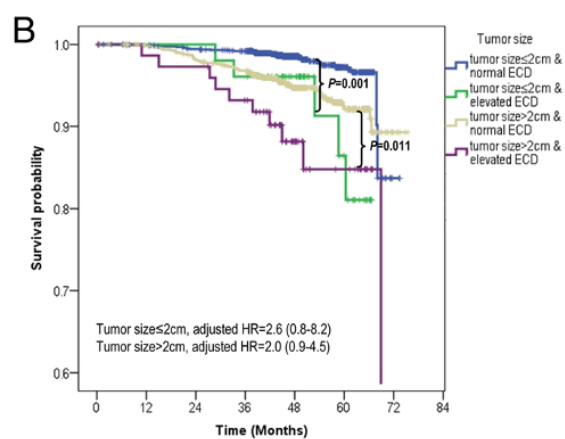

D

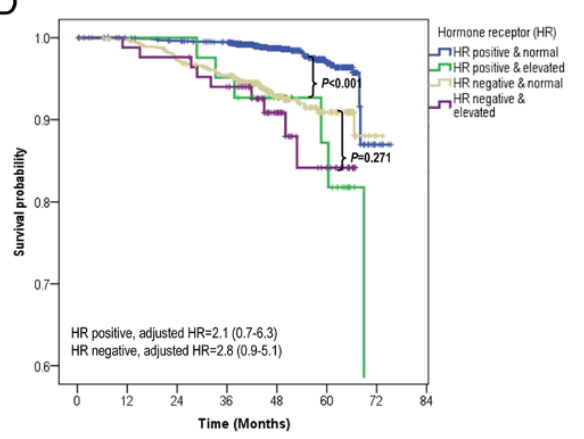

F

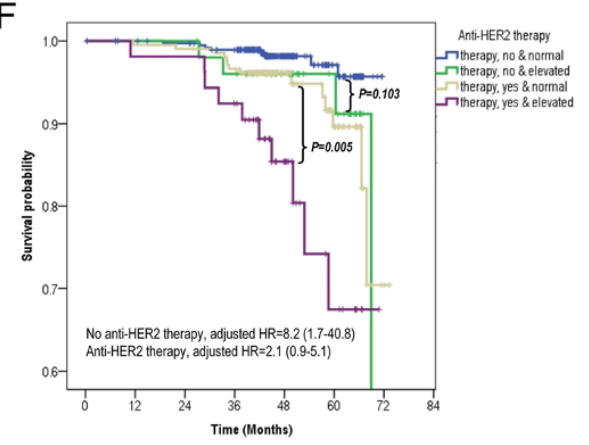

Figure 5 Breast-cancer-specific survival (BCSS) according to serum HER2 ECD level. (A) BCSS according to serum HER2 ECD level [elevated (>15.2 ng/ml) vs normal ( $\leq 15.2 \mathrm{ng} / \mathrm{ml})$ ] in the overall series (B-F) Subgroup analyses by tumor size (B), LN status (C), hormone-receptor status (D), tissue HER2 status (E), and anti-HER2 therapy (F). (A-F) No adjusted HRs in each subgroup were found to be independently significant, except in the subgroup with positive tissue HER2 status (adjusted $\mathrm{HR}=2.6,95 \% \mathrm{Cl}=1.2-5.3$ ) and nontrastuzumab (adjusted $\mathrm{HR}=8.2,95 \% \mathrm{Cl}=1.7-40.8$ ). All HRs were adjusted according to the following eight variables: tumor size, LN status, tumor grade, lymphovascular invasion, tissue HER2 status, chemotherapy, antihormone therapy, and trastuzumab therapy.

We classified all 2,860 patients into 3 subgroups according to HER2 status [i.e., positive $(+)$ and negative $(-)]$ in both tissue and serum: tissue-, irrespective of serum status $(n=2,168)$, tissue $+/$ serum $-(n=588)$, and tissue+/serum $+(n=104)$. As shown in Figure 6, despite tissue HER2 overexpression being a significant prognostic factor in all patients for DMFS and BCSS (log-rank $P=$ 0.015 and 0.035 , respectively; data not shown), comparison of the three subgroups revealed that the DMFS and BCSS did not differ between the tissue+/serum- and tissue- subgroups $(P=0.793$ and 0.627 , respectively; Figure $6 \mathrm{~A}, \mathrm{~B})$. The tissue+/serum + subgroup had the most ominous prognosis, which suggests a significant role of serum HER2 ECD level as a prognosticator in the tissue HER2-positive patients. In addition to applying the dichotomizing cutoff value of $15.2 \mathrm{ng} / \mathrm{ml}$, four subgroups categorized by serum HER2 ECD levels, only in 692 patients with positive tissue HER2 status, exhibited a trend toward a dose-response relationship in terms of prognosis: higher serum HER2 ECD levels were associated with worse DMFS and BCSS (Figure 6C,D).

The two Cox proportional-hazards models given in Table 4 suggested that HER2 ECD level was a robust independent prognostic factor in patients with tissue HER2- 

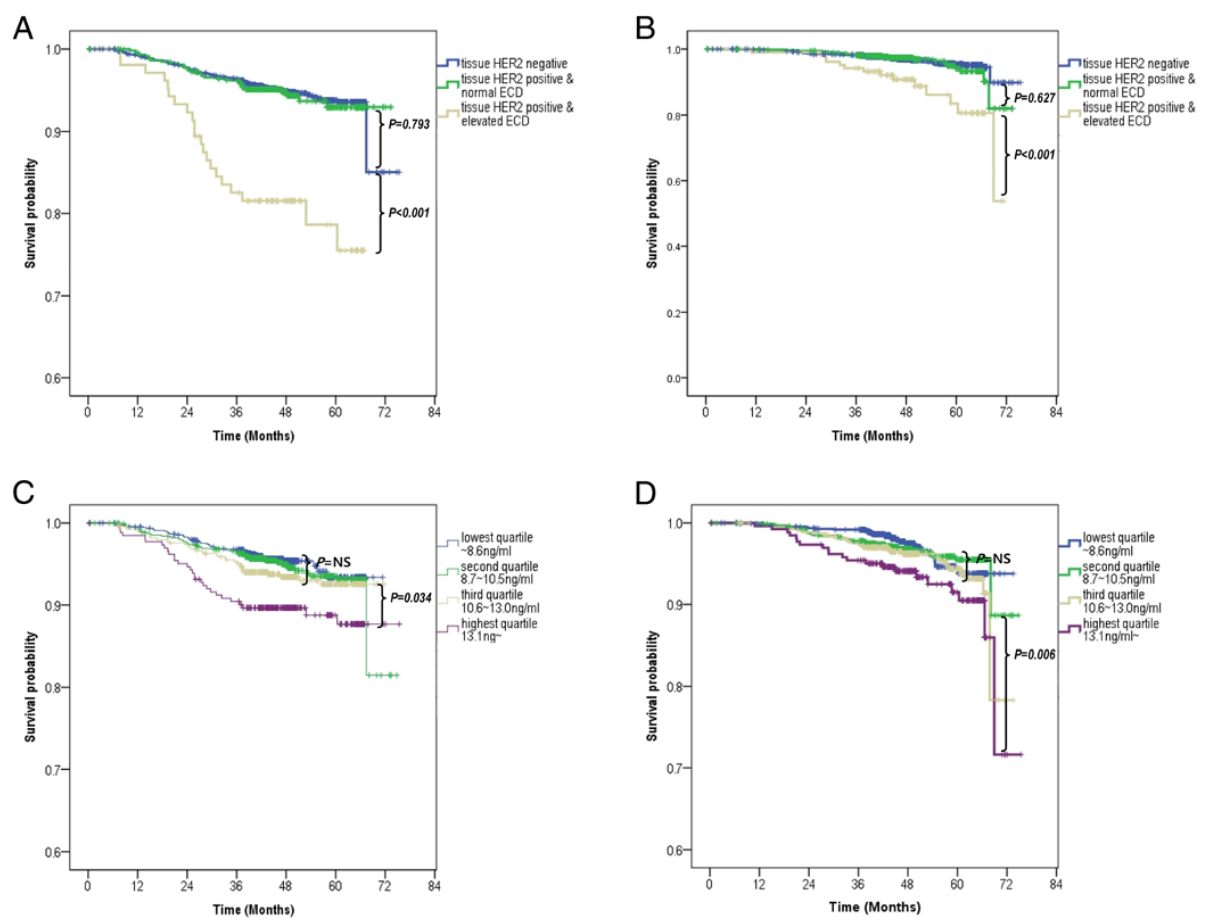

Figure 6 Distant-metastasis-free survival (DMFS) and breast-cancer-specific survival (BCSS) according to HER2 status in both tissue and serum. DMFS (A) and BCSS (B) among three subgroups classified according to both tissue and serum HER2 status: tissue- irrespective of serum status, tissue+/serum-, and tissue+/serum+. (C,D) There was a significant trend toward a reduction in survival with increasing serum HER2 ECD values in only 692 patients with a positive tissue HER2 status.

positive breast cancer, irrespective of the variable tentative cutoff values: elevated $\nu$ s normal $(\mathrm{HR}=3.788,95 \%$ $\mathrm{CI}=2.034-7.058, P<0.001$, Table 4$)$ and third/highest quartile vs lowest quartile (third quartile: $\mathrm{HR}=3.029$, 95\% CI $=1.003-9.152, P=0.049$; highest quartile: $\mathrm{HR}=$ 4.746, $95 \% \mathrm{CI}=1.591-14.160, P=0.005$; Table 4 ).

\section{Discussion}

The present study found that serum HER2 ECD level was correlated with a poor prognosis in primary breast cancer, and that patients with an elevated HER2 ECD level $(>15.2 \mathrm{ng} / \mathrm{ml})$ had a worse DMFS and BCSS than those with normal HER2 ECD levels. In particular, it was confirmed that its role as an independent prognostic factor was clinically robust at various tentative cutoff values in patients with positive tissue HER2 status.

There is still no general consensus as to a definitive dichotomizing HER2 ECD cutoff value for clinical use, so we adopted the most commonly used value of $15.2 \mathrm{ng} / \mathrm{ml}$ to define elevated HER2 ECD. HER2 ECD levels were previously reported to be elevated in 11.4\% (range, 3.1$34.1 \%$ ) of primary breast cancer patients and 36.5\% (range, 23-62\%) of metastatic breast cancer patients [34]. In the present study, elevated HER2 ECD levels were observed in $4.4 \%(126 / 2,862)$ of the primary breast cancer patients, which is a noteworthy finding because it was derived from a large number of patients at a single institute and using a single US FDA-approved assay. In addition, as shown in Table 1, significant differences in the prevalence of elevated HER2 ECD levels between the subgroups were confirmed, which is in accordance with previous results $[30,36]$. And, other studies have suggested that setting a lower cutoff value such as $7.7 \mathrm{ng} / \mathrm{ml}$ and $10.2 \mathrm{ng} / \mathrm{ml}$ or analyzing early stage patients could come with a better outcome, however our additional study adjusted with these did not show a better result (Figure 7). However, it should be noticed that, our analysis did not address the issues on more optimal cutoff values for HER2 ECD raised by previous studies $[31,38,39]$.

Interestingly, elevated serum HER2 ECD levels were detected in $22(1.0 \%)$ of the 2,168 tissue HER2-negative patients $(26.4 \pm 35.6 \mathrm{ng} / \mathrm{ml}$; range, $15.3-184.4 \mathrm{ng} / \mathrm{ml})$. Possible explanations for this are chance false-positivity, normal elevation of serum HER2 ECD level as reported in healthy controls [40], a minority of HER2-positive cells being lower than the definition of tissue HER2 positivity as its source [41], and genetic differences between individuals with respect to matrix metalloproteinase activity, which is responsible for HER2 release into the serum [39]. Since metastasis had occurred in only 1 of the 22 patients in this subgroup, the clinical implication of unexpected serum ECD elevation could not be further investigated. 
Table 4 Cox proportional-hazards regression model for distant-metastasis-free survival (DMFS) and breast-cancerspecific survival (BCSS) in 692 patients with tissue HER2-positive breast cancer

\begin{tabular}{|c|c|c|c|c|c|c|}
\hline \multirow[t]{2}{*}{ Variable } & \multicolumn{3}{|c|}{ DMFS } & \multicolumn{3}{|c|}{ BCSS } \\
\hline & $\mathrm{HR}$ & $95 \% \mathrm{Cl}$ & $P$ & HR & $95 \% \mathrm{Cl}$ & $P$ \\
\hline \multicolumn{7}{|c|}{ Model with dichotomized serum HER2 ECD level, elevated vs normal } \\
\hline Serum HER2 ECD level, >15.2 ng/ml & 3.788 & $2.034-7.054$ & $<0.001^{\mathrm{a}}$ & 2.564 & $1.230-5.343$ & $0.012^{\mathrm{a}}$ \\
\hline Tumor size, $>2 \mathrm{~cm}$ & 1.731 & $0.859-3.487$ & 0.125 & 1.134 & $0.515-2.497$ & 0.754 \\
\hline Lymph node positive & 2.614 & $1.011-6.756$ & $0.047^{\mathrm{a}}$ & 2.428 & $0.812-7.257$ & 0.112 \\
\hline Grade 3+ & 1.972 & $1.069-3.638$ & $0.030^{a}$ & 1.575 & $0.758-3.270$ & 0.223 \\
\hline Lymphovascular invasion & 2.625 & $1.419-4.855$ & $0.002^{\mathrm{a}}$ & 2.740 & $1.315-5.709$ & $0.007^{\mathrm{a}}$ \\
\hline Chemotherapy, yes & 0.235 & $0.081-0.687$ & $0.008^{\mathrm{a}}$ & 0.303 & $0.085-1.078$ & 0.065 \\
\hline Hormone therapy, yes & 1.576 & $0.841-2.951$ & 0.156 & 1.032 & $0.494-2.156$ & 0.933 \\
\hline Trastuzumab, received & 1.734 & $0.902-3.332$ & 0.099 & 1.969 & $0.903-4.292$ & 0.089 \\
\hline \multicolumn{7}{|c|}{ Model with four subgroups classified by serum HER2 ECD levels, each quartile group vs lowest-quartile subgroup } \\
\hline \multicolumn{7}{|l|}{ Serum HER2 ECD level, } \\
\hline Lowest quartile (reference) & 1 & & & 1 & & \\
\hline Second quartile & 1.827 & $0.549-6.078$ & 0.326 & 1.008 & $0.224-4.529$ & 0.992 \\
\hline Third quartile & 3.029 & $1.003-9.152$ & $0.049^{\mathrm{a}}$ & 2.407 & $0.669-8.655$ & 0.179 \\
\hline Highest quartile & 4.746 & $1.591-14.160$ & $0.005^{\mathrm{a}}$ & 2.826 & $0.785-10.176$ & 0.112 \\
\hline Tumor size, $>2 \mathrm{~cm}$ & 1.741 & $0.864-3.507$ & 0.121 & 1.146 & $0.519-2.534$ & 0.736 \\
\hline Lymph node positive & 2.502 & $0.982-6.376$ & 0.055 & 2.407 & $0.804-7.211$ & 0.117 \\
\hline Grade 3+ & 1.844 & $1.010-3.370$ & $0.046^{\mathrm{a}}$ & 1.844 & $1.010-3.370$ & $0.046^{\mathrm{a}}$ \\
\hline Lymphovascular invasion & 2.303 & $1.250-4.240$ & $0.007^{\mathrm{a}}$ & 2.550 & $1.223-5.317$ & $0.012^{\mathrm{a}}$ \\
\hline Chemotherapy, yes & 0.210 & $0.074-0.599$ & $0.004^{\mathrm{a}}$ & 0.273 & $0.078-0.957$ & $0.042^{\mathrm{a}}$ \\
\hline Hormone therapy, yes & 1.443 & $0.784-2.655$ & 0.238 & 1.038 & $0.501-2.150$ & 0.920 \\
\hline Trastuzumab, received & 1.930 & $1.013-3.677$ & $0.045^{\mathrm{a}}$ & 2.098 & $0.968-4.549$ & 0.061 \\
\hline
\end{tabular}

${ }^{\mathrm{a}}$ Significant at $P<0.05$.

In this study we observed a significant association between elevated HER2 ECD level and the parameters of tumor aggressiveness (Table 2). More patients had undergone mastectomy among those with an elevated HER2 ECD levels than in those with a normal HER2 ECD level. This might be caused by the tumor characteristics being more aggressive in the former subgroup than in the latter, the cause of which was not fully established.

The association between serum HER2 ECD concentration and tissue HER2 status remains controversial in primary breast cancer, which may be attributable to the use of different cutoff values, small samples, and different patient populations in the various studies. For now it seems reasonable to suggest that serum HER2 ECD levels cannot substitute for tissue HER2 expression, but can provide additional information. The aim of the present study was to compare the concordances according to the subgroups and provide practical information when we suspected the inherent imperfection of tissue HER2 results in the case of elevated serum HER2 ECD levels. We applied two cutoff values: $15.2 \mathrm{ng} / \mathrm{ml}$, which has been approved by the US FDA; and $10.2 \mathrm{ng} / \mathrm{ml}$, which has been suggested as a more appropriate cutoff value for the Korean population [31]. Although a lower cutoff value could yield a higher sensitivity and negative predictive value (Table 3), it negatively affected the specificity and positive predictive value. In our opinion, in view of the adjunctive role of serum HER2 ECD level, the cutoff of $15.2 \mathrm{ng} / \mathrm{ml}$ may have greater clinical utility because higher specificity and positive predictive values are mandatory to reduce the likelihood of false suspicion of tissue HER2 status due to the abnormal serum HER2 ECD level. Unlike previous studies [35,36], the present findings suggest that significant correlations between the expression of tissue HER2 and serum HER2 ECD level exist in primary breast tumor, regardless of whether the primary tumor is early or advanced (Table 3). However, the finding that AUCs increased as the indexes of tumor extent increased should not be overlooked (Figure 3).

Despite the relatively short follow-up, the inclusion of a large sample enabled us to demonstrate the poor prognostic role of HER2 ECD level. Moreover, we determined that tissue HER2 status had no prognostic impact on either DMFS or BCSS in patients with a normal serum HER2 

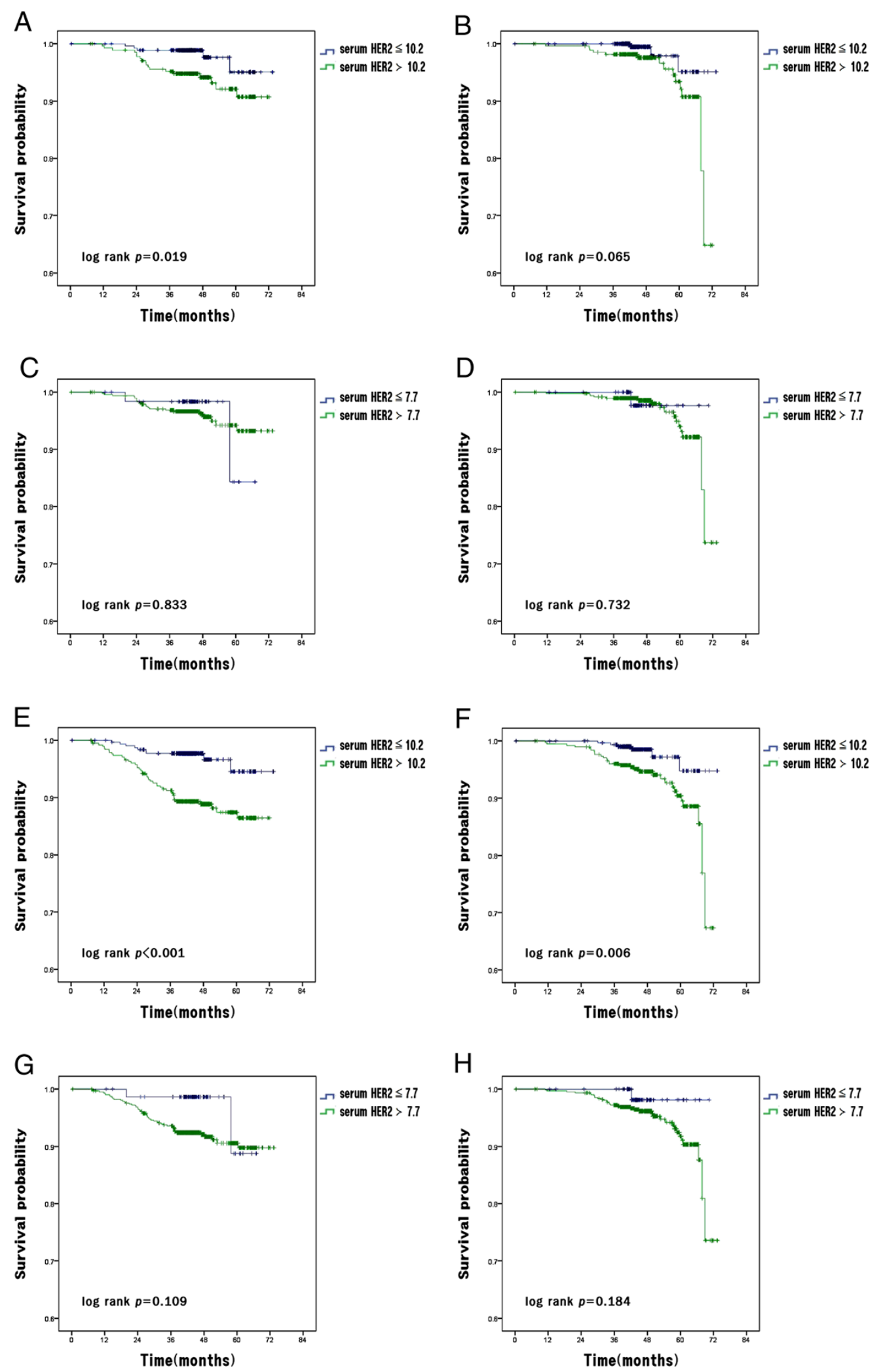

Figure 7 (See legend on next page.) 
(See figure on previous page.)

Figure 7 Distant-metastasis-free survival (DMFS) and Breast-cancer-specific survival (BCSS) according to the serum HER2 ECD level by the lower cutoffs and the early stages. (A) DMFS according to serum HER2 ECD level [elevated level $(>10.2 \mathrm{ng} / \mathrm{ml}) \mathrm{vs}$ normal level $(\leq 10.2 \mathrm{ng} / \mathrm{ml})$ ] in breast cancer patients with stage I and II. (B) BCSS according to serum HER2 ECD level [elevated level $(>10.2 \mathrm{ng} / \mathrm{ml}) \mathrm{vs}$ normal level $(\leq 10.2 \mathrm{ng} / \mathrm{ml})$ ] in breast cancer patients with stage I and II (C) DMFS according to serum HER2 ECD level [elevated level $(>7.7 \mathrm{ng} / \mathrm{ml}) \mathrm{vs} \mathrm{normal} \mathrm{level}(\leq 7.7 \mathrm{ng} / \mathrm{ml})$ ] in breast cancer patients with stage I and II (D) BCSS according to serum HER2 ECD level [elevated level $(>7.7 \mathrm{ng} / \mathrm{ml})$ vs normal level $(\leq 7.7 \mathrm{ng} / \mathrm{ml})$ in breast cancer patients with stage I and II (E) DMFS according to serum HER2 ECD level [elevated level $(>10.2 \mathrm{ng} / \mathrm{ml})$ vs normal level $(\leq 10.2 \mathrm{ng} / \mathrm{ml})]$ in breast cancer patients with stage I, II and III (F) BCSS according to serum HER2 ECD level [elevated level $(>10.2 \mathrm{ng} / \mathrm{ml})$ vs normal level $(\leq 10.2 \mathrm{ng} / \mathrm{mll})$ in breast cancer patients with stage I, II and III (G) DMFS according to serum HER2 ECD level [elevated level ( $>7.7 \mathrm{ng} / \mathrm{ml}) \mathrm{vs}$ normal level $(\leq 7.7 \mathrm{ng} / \mathrm{ml})$ ] in breast cancer patients with stage I, II and III (H) BCSS according to serum HER2 ECD level [elevated level $(>7.7 \mathrm{ng} / \mathrm{ml})$ vs normal level $(\leq 7.7 \mathrm{ng} / \mathrm{ml})$ ] in breast cancer patients with stage I, II and III.

ECD level. Thus, the serum HER2 ECD level can be a valuable prognostic factor in patients with primary breast cancer with tissue HER2 overexpression (Figure 6 and Table 4). The persistent adverse prognostic value of elevated HER2 ECD levels in stage I/II early breast cancer could reflect the presence of micrometastases or high rates of HER2 cleavage and shedding, with the production of truncated cell-associated fragments that contain the signaling kinase domain that is activated in the absence of the ECD. As a result, these tumors with a deregulated growth-promoting pathway could behave more aggressively [30].

To clarify the possibility of false-positive results in the present study in terms of prognosis according to the arbitrary cutoff value of $15.2 \mathrm{ng} / \mathrm{ml}$, we validated its prognostic role among continuous subgroups classified relative to the quartile values of serum HER2 ECD levels in tissue HER2-positive tumors: the lowest-quartile, median, and highest-quartile values were $8.7,10.6$, and $13.1 \mathrm{ng} / \mathrm{ml}$, respectively. The Kaplan-Meier curves (Figure 6C, D) and multivariate analysis revealed that the third- and highestquartile subgroups independently had an ominous prognosis in terms of DMFS (third quartile: $\mathrm{HR}=3.029,95 \%$ $\mathrm{CI}=1.003-9.152, P=0.049$; highest quartile: $\mathrm{HR}=4.746$, $95 \% \mathrm{CI}=1.591-14.160, P=0.005$; Table 4).

The possibility of an association between HER2 ECD level and trastuzumab response was assessed in 264 patients receiving trastuzumab and in 428 patients without trastuzumab administration. We found that HER2 ECD level was a poor prognostic indicator, irrespective of the treatment in terms of DMFS (Figure 4F). In terms of BCSS, there did not appear to be a significant prognostic role of elevated HER2 ECD level in the trastuzumab subgroup (Figure 5F). This lack of a significant finding may be attributable to the relatively short follow-up. Also, only $38.2 \%(264 / 692)$ of patients with HER2-positive tumors had been treated with trastuzumab in the cohort. It is partly related to the inclusion of patients with small tumors. Our study did not include patients receiving neoadjuvant systemic therapy. More importantly, the use of trastuzumab in the adjuvant setting was just covered for advanced breast cancer by the Korean national health insurance during the period of this study (2007 2009). In patients with tissue HER2 positive, T1 was 54.5\% (377/ 692), and N0 was $54.0 \%$ (374/692), which needs to be taken into consideration. Due to the nature of a retrospective analysis without randomization, it was not possible to compare the responses or benefits of trastuzumab among the subgroups of 261 patients who received this drug with elevated $(n=53)$ and normal $(n=208)$ HER2 ECD levels.

While the present study is subject to the same limitations as other retrospective studies, it provides robust evidence supporting the valuable clinical utility of HER2 ECD level, drawn successfully because of the inclusion of a large sample. The presented results indicate that a preoperatively elevated HER2 ECD level reflects tumor extension, with significantly higher values being found in patients with larger tumors, with LN metastasis, or with LVI, and that patients with an elevated HER2 ECD level are more likely to develop distant metastasis irrespective of their disease status.

\section{Conclusions}

Given the prevalence of HER2 ECD elevation, preoperative serum HER2 ECD measurement can be clinically useful in patients with tissue HER2-positive primary breast cancer.

\section{Abbreviations}

BCSS: Breast-cancer-specific survival; DMFS: Distant-metastasis-free survival; ECD: Extracellular domain; FISH: Fluorescence in situ hybridization; HER2: Human epidermal growth factor receptor-2; IHC: Immunohistochemistry.

\section{Competing interests}

The authors declare that they have no competing interests.

\section{Authors' contributions}

All authors have made substantial contributions to conception and design, acquisition of data, or analysis and interpretation of data. SBL and JWL conceived the study and directly participated in the whole process throughout the study. JWL, JHY, BSK, HJK, BHS, SHA, and SBK participated in its design and coordination and acquisition of clinical data. GYG and HJL evaluated the adequacy for tissue HER2 examination and WL for serum HER ECD measurements. KHJ and JHA participated in interpreting the results. JWL and JS participated in the statistical analysis and helped to draft the manuscript. All authors read and approved the final manuscript.

\section{Acknowledgements}

This study was supported by a grant from the National R\&D Program, Ministry of Trade, Industry and Energy, Republic of Korea (No. 10045947). 


\section{Author details}

${ }^{1}$ Department of Surgery, University of Ulsan College of Medicine, Asan Medical Center, 388-1 Pungnap 2 dong, Songpa-Gu, Seoul 138-736, Korea. ${ }^{2}$ Department of Pathology, University of Ulsan College of Medicine, Asan Medical Center, Seoul, Korea. ${ }^{3}$ Department of Oncology, University of Ulsan College of Medicine, Asan Medical Center, Seoul, Korea. ${ }^{4}$ Department of Laboratory Medicine, University of Ulsan College of Medicine, Asan Medical Center, Seoul, Korea. ${ }^{5}$ Department of Epidemiology, School of Public Health and Institute of Health and Environment, Seoul National University, Seoul, Korea.

Received: 10 May 2014 Accepted: 3 December 2014

Published: 10 December 2014

\section{References}

1. Untch M, Rezai M, Loibl S, Fasching PA, Huober J, Tesch H, Bauerfeind I, Hilfrich J, Eidtmann H, Gerber B, Hanusch C, Kuhn T, du Bois A, Blohmer JU, Thomssen C, Dan Costa S, Jackisch C, Kaufmann M, Mehta K, von Minckwitz G: Neoadjuvant treatment with trastuzumab in HER2-positive breast cancer: results from the GeparQuattro study. J Clin Oncol 2010, 28:2024-2031.

2. Smith I, Procter M, Gelber RD, Guillaume S, Feyereislova A, Dowsett M, Goldhirsch A, Untch M, Mariani G, Baselga J, Kaufmann M, Cameron D, Bell R, Bergh J, Coleman R, Wardley A, Harbeck N, Lopez RI, Mallmann P, Gelmon K, Wilcken N, Wist E, Sanchez Rovira P, Piccart-Gebhart MJ, team Hs: 2-year follow-up of trastuzumab after adjuvant chemotherapy in HER2-positive breast cancer: a randomised controlled trial. Lancet 2007, 369:29-36.

3. Slamon DJ, Leyland-Jones B, Shak S, Fuchs H, Paton V, Bajamonde A, Fleming T, Eiermann W, Wolter J, Pegram M, Baselga J, Norton L: Use of chemotherapy plus a monoclonal antibody against HER2 for metastatic breast cancer that overexpresses HER2. N Engl J Med 2001, 344:783-792.

4. Slamon DJ, Clark GM, Wong SG, Levin WJ, Ullrich A, McGuire WL: Human breast cancer: correlation of relapse and survival with amplification of the HER-2/neu oncogene. Science 1987, 235:177-182.

5. Berns EM, Foekens JA, van Staveren IL, van Putten WL, de Koning HY, Portengen $\mathrm{H}$, Klijn JG: Oncogene amplification and prognosis in breast cancer: relationship with systemic treatment. Gene 1995, 159:11-18.

6. Muss HB, Thor AD, Berry DA, Kute T, Liu ET, Koerner F, Cirrincione CT, Budman DR, Wood WC, Barcos M, Henderson IC: c-erbB-2 expression and response to adjuvant therapy in women with node-positive early breast cancer. N Engl J Med 1994, 330:1260-1266.

7. Paik S, Bryant J, Park C, Fisher B, Tan-Chiu E, Hyams D, Fisher ER, Lippman ME, Wickerham DL, Wolmark N: erbB-2 and response to doxorubicin in patients with axillary lymph node-positive, hormone receptor-negative breast cancer. J Natl Cancer Inst 1998, 90:1361-1370.

8. Borg A, Baldetorp B, Ferno M, Killander D, Olsson H, Ryden S, Sigurdsson H: ERBB2 amplification is associated with tamoxifen resistance in steroidreceptor positive breast cancer. Cancer Lett 1994, 81:137-144.

9. Carlomagno C, Perrone F, Gallo C, De Laurentiis M, Lauria R, Morabito A, Pettinato G, Panico L, D'Antonio A, Bianco AR, De Placido S: c-erb B2 overexpression decreases the benefit of adjuvant tamoxifen in early-stage breast cancer without axillary lymph node metastases. J Clin Oncol 1996, 14:2702-2708.

10. Ross JS, Fletcher JA: The HER-2/neu oncogene in breast cancer: prognostic factor, predictive factor, and target for therapy. Oncologist 1998, 3:237-252.

11. Wolff AC, Hammond ME, Schwartz JN, Hagerty KL, Allred DC, Cote RJ, Dowsett M, Fitzgibbons PL, Hanna WM, Langer A, McShane LM, Paik S, Pegram MD, Perez EA, Press MF, Rhodes A, Sturgeon C, Taube SE, Tubbs R, Vance $\mathrm{GH}$, van de Vijver M, Wheeler TM, Hayes DF, American Society of Clinical O, College of American P: American society of clinical oncology/ college of American pathologists guideline recommendations for human epidermal growth factor receptor 2 testing in breast cancer. $J$ Clin Oncol 2007, 25:118-145.

12. Perez EA, Dueck AC, McCullough AE, Reinholz MM, Tenner KS, Davidson NE, Gralow J, Harris LN, Kutteh LA, Hillman DW, Jenkins RB, Chen B: Predictability of adjuvant trastuzumab benefit in N9831 patients using the ASCO/CAP HER2-positivity criteria. J Nat/ Cancer Inst 2012, 104:159-162.

13. Wolff AC, Hammond ME, Hicks DG, Dowsett M, McShane LM, Allison KH, Allred DC, Bartlett JM, Bilous M, Fitzgibbons P, Hanna W, Jenkins RB, Mangu PB, Paik S, Perez EA, Press MF, Spears PA, Vance GH, Viale G, Hayes DF, American Society of Clinical O, College of American P: Recommendations for human epidermal growth factor receptor 2 testing in breast cancer: American society of clinical oncology/college of American pathologists clinical practice guideline update. J Clin Oncol 2013, 31:3997-4013.

14. Lam L, McAndrew N, Yee M, Fu T, Tchou JC, Zhang H: Challenges in the clinical utility of the serum test for HER2 ECD. Biochim Biophys Acta 1826, 2012:199-208

15. Paik S, Kim C, Wolmark N: HER2 status and benefit from adjuvant trastuzumab in breast cancer. N Engl J Med 2008, 358:1409-1411.

16. Zabrecky JR, Lam T, McKenzie SJ, Carney W: The extracellular domain of p185/neu is released from the surface of human breast carcinoma cells, SK-BR-3. J Biol Chem 1991, 266:1716-1720

17. Pupa SM, Menard S, Morelli D, Pozzi B, De Palo G, Colnaghi Ml: The extracellular domain of the c-erbB-2 oncoprotein is released from tumor cells by proteolytic cleavage. Oncogene 1993, 8:2917-2923.

18. Codony-Servat J, Albanell J, Lopez-Talavera JC, Arribas J, Baselga J: Cleavage of the HER2 ectodomain is a pervanadate-activable process that is inhibited by the tissue inhibitor of metalloproteases- 1 in breast cancer cells. Cancer Res 1999, 59:1196-1201.

19. Paik S, Bryant J, Tan-Chiu E, Romond E, Hiller W, Park K, Brown A, Yothers G, Anderson S, Smith R, Wickerham DL, Wolmark N: Real-world performance of HER2 testing-national surgical adjuvant breast and bowel project experience. J Natl Cancer Inst 2002, 94:852-854.

20. Yeh IT: Measuring HER-2 in breast cancer. Immunohistochemistry, FISH, or ELISA? Am J Clin Pathol 2002, 117(Suppl):S26-S35.

21. Kong SY, Nam BH, Lee KS, Kwon Y, Lee ES, Seong MW, Lee do H, Ro J: Predicting tissue HER2 status using serum HER2 levels in patients with metastatic breast cancer. Clin Chem 2006, 52:1510-1515.

22. Fehm T, Becker S, Duerr-Stoerzer S, Sotlar K, Mueller V, Wallwiener D, Lane

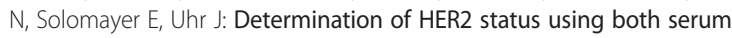
HER2 levels and circulating tumor cells in patients with recurrent breast cancer whose primary tumor was HER2 negative or of unknown HER2 status. Breast Cancer Res 2007, 9:R74.

23. Classen S, Kopp R, Possinger K, Weidenhagen R, Eiermann W, Wilmanns W: Clinical relevance of soluble c-erbB-2 for patients with metastatic breast cancer predicting the response to second-line hormone or chemotherapy. Tumour Biol 2002, 23:70-75

24. Yamauchi H, O'Neill A, Gelman R, Carney W, Tenney DY, Hosch S, Hayes DF: Prediction of response to antiestrogen therapy in advanced breast cancer patients by pretreatment circulating levels of extracellular domain of the HER-2/c-neu protein. J Clin Oncol 1997, 15:2518-2525.

25. Mehta RR, McDermott JH, Hieken TJ, Marler KC, Patel MK, Wild LD, Das Gupta TK: Plasma c-erbB-2 levels in breast cancer patients: prognostic significance in predicting response to chemotherapy. J Clin Oncol 1998, 16:2409-2416

26. Muller V, Witzel I, Pantel K, Krenkel S, Luck HJ, Neumann R, Keller T, Dittmer J, Janicke F, Thomssen C: Prognostic and predictive impact of soluble epidermal growth factor receptor (sEGFR) protein in the serum of patients treated with chemotherapy for metastatic breast cancer. Anticancer Res 2006, 26:1479-1487.

27. Hoopmann M, Neumann R, Tanasale T, Schondorf T: HER-2/neu determination in blood plasma of patients with HER-2/neu overexpressing metastasized breast cancer: a longitudinal study. Anticancer Res 2003, 23:1031-1034.

28. Schondorf T, Hoopmann M, Warm M, Neumann R, Thomas A, Gohring UJ, Eisberg C, Mallmann P: Serologic concentrations of HER-2/neu in breast cancer patients with visceral metastases receiving trastuzumab therapy predict the clinical course. Clin Chem 2002, 48:1360-1362.

29. Colomer R, Montero S, Lluch A, Ojeda B, Barnadas A, Casado A, Massuti B, Cortes-Funes $H$, Lloveras B: Circulating HER2 extracellular domain and resistance to chemotherapy in advanced breast cancer. Clin Cancer Res 2000, 6:2356-2362.

30. Ludovini V, Gori S, Colozza M, Pistola L, Rulli E, Floriani I, Pacifico E, Tofanetti FR, Sidoni A, Basurto C, Rulli A, Crino L: Evaluation of serum HER2 extracellular domain in early breast cancer patients: correlation with clinicopathological parameters and survival. Ann Oncol 2008, 19:883-890.

31. Kong SY, Kang JH, Kwon Y, Kang HS, Chung KW, Kang SH, Lee DH, Ro J, Lee ES: Serum HER-2 concentration in patients with primary breast cancer. J Clin Pathol 2006, 59:373-376.

32. Molina R, Auge JM, Escudero JM, Filella X, Zanon G, Pahisa J, Farrus B, Munoz M, Velasco M: Evaluation of tumor markers (HER-2/neu oncoprotein, CEA, and CA 15.3) in patients with locoregional breast cancer: prognostic value. Tumour Biol 2010, 31:171-180.

33. Quaranta M, Daniele A, Coviello M, Savonarola A, Abbate I, Venneri MT Paradiso A, Stea B, Zito A, Labriola A, Schittulli F: c-erbB-2 protein level in 
tissue and sera of breast cancer patients: a possibly useful clinical correlation. Tumori 2006, 92:311-317.

34. Leary AF, Hanna WM, van de Vijver MJ, Penault-Llorca F, Ruschoff J, Osamura RY, Bilous M, Dowsett M: Value and limitations of measuring HER-2 extracellular domain in the serum of breast cancer patients. J Clin Oncol 2009, 27:1694-1705.

35. Narita T, Funahashi H, Satoh Y, Takagi H: C-erbB-2 protein in the sera of breast cancer patients. Breast Cancer Res Treat 1992, 24:97-102

36. Garoufali A, Kyriakou F, Kountourakis P, Yioti I, Malliou S, Nikaki A, Kardara E, Frangos I, Koumna S, Baziotis N, Scorilas A, Ardavanis A: Extracellular domain of HER2: a useful marker for the initial workup and follow-up of HER2-positive breast cancer. J BUON 2008, 13:409-413.

37. Singletary SE, Allred C, Ashley P, Bassett LW, Berry D, Bland KI, Borgen PI, Clark G, Edge SB, Hayes DF, Hughes LL, Hutter RV, Morrow M, Page DL, Recht A, Theriault RL, Thor A, Weaver DL, Wieand HS, Greene FL: Revision of the American joint committee on cancer staging system for breast cancer. J Clin Oncol 2002, 20:3628-3636.

38. Badzek S, Kelovic VL, Plestina S, Humar I, Veir Z, Mihaljevic Z: Serum HER2/ $E C D$ value in stage I and II early breast cancer: need of a lower cut-off? Wien Klin Wochenschr 2011, 123:726-731.

39. Ma L, Yang HY, Han XH, Li J, Wang F, Zhang CL, Yao JR, Shi YK: Relationship between serum HER2 extracellular domain levels, tissue HER2 expression, and clinico-pathological parameters in early stage breast cancer. Chin Med J (Engl) 2012, 125:4104-4110

40. Asgeirsson KS, Agrawal A, Allen C, Hitch A, Ellis IO, Chapman C, Cheung KL, Robertson JF: Serum epidermal growth factor receptor and HER2 expression in primary and metastatic breast cancer patients. Breast Cancer Res 2007, 9:R75.

41. Sorensen PD, Jakobsen EH, Langkjer ST, Bokmand S, Ostergaard B, Olsen DA, Madsen JS, Brandslund I: Serum HER-2 concentrations for monitoring women with breast cancer in a routine oncology setting. Clin Chem Lab Med 2009, 47:1117-1123.

doi:10.1186/1471-2407-14-929

Cite this article as: Lee et al:: Preoperative serum HER2 extracellular domain levels in primary invasive breast cancer. BMC Cancer 2014 14:929.

\section{Submit your next manuscript to BioMed Central and take full advantage of:}

- Convenient online submission

- Thorough peer review

- No space constraints or color figure charges

- Immediate publication on acceptance

- Inclusion in PubMed, CAS, Scopus and Google Scholar

- Research which is freely available for redistribution 